\title{
ACCIDENTAL VACCINIA*
}

\author{
BY \\ CHARLES TAYLOR
}

Shrewsbury '

Case Report

A married woman, aged 25, had been vaccinated in childhood. Her baby was vaccinated on January 6, 1955, and the mother's right eye became irritable on January 19. She was treated by her own doctor with intra-muscular penicillin, sulphathiazole by mouth, and sulphacetamide drops in the eye, and was referred to the Eye, Ear, and Throat Hospital, Shrewsbury, on January 25, 1955.

Fig. 1 shows her condition on admission. There were pustules on the margins of the lids of the right eye, one high up on the right cheek, and one at the muco-cutaneous junction of the right nostril. The right pre-auricular gland was enlarged. She was treated locally with ung. aureomycin, and a drop of atropine was instilled into the conjunctival sac although the cornea was not affected. Chloramphenicol was administered by mouth, and vitamin B complex was given to offset the inhibitive action of the antibiotics on its synthesis in the bowel.

On January 27 the condition had advanced (Fig. 2). The right eye was closed by oedema and a few small pustules appeared in the right temple region (not shown well on the photograph). It was now impossible to see the right cornea. Pustules had appeared at the muco-cutaneous junction of the left nostril and on the lid margins of the left eye. Pre- and post-auricular and cervical glands were enlarged on both sides. A supply of vaccinia gamma globulin was obtained in solid form and reconstituted by the addition of distilled water. $20 \mathrm{ml}$. were injected intramuscularly on the morning of January 28.

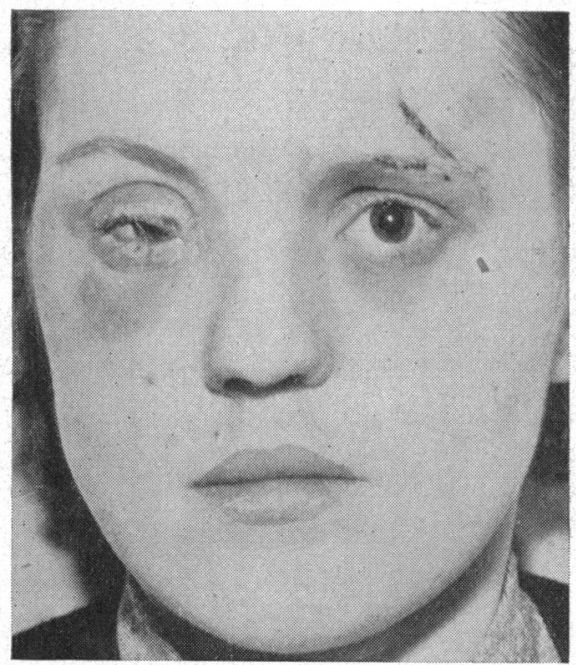

FIG. 1.-Patient's appearance on admission (January 25, 1956).

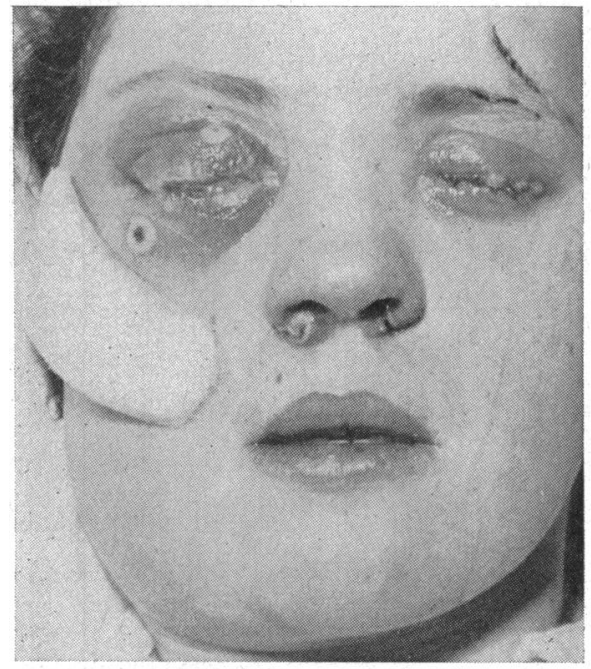

Fig. 2.-Appearance 2 days later. (January 27, 1956).

* Received for publication November 26, 1956. 
The patient felt better that evening, and the dose was repeated the next morning, January 29. The small pustules in the right temple region had now disappeared and the lids were much less swollen. The patient felt much better and the temperature had subsided (Table). The dregs in the bottles had some distilled water added and were used locally as

TABLE

TEMPERATURE, PULSE, AND RESPIRATION DURING FIRST 7 DAYS IN HOSPITAL

\begin{tabular}{|c|c|c|c|c|c|c|c|c|c|c|c|c|c|c|c|}
\hline \multirow[t]{2}{*}{ Date .. } & \multirow[t]{2}{*}{. } & \multirow[t]{2}{*}{. } & \multirow{2}{*}{$\frac{25}{\text { p.m. }}$} & \multicolumn{2}{|c|}{26} & \multicolumn{2}{|c|}{27} & \multicolumn{2}{|c|}{28} & \multicolumn{2}{|c|}{29} & \multicolumn{2}{|c|}{30} & \multicolumn{2}{|c|}{31} \\
\hline & & & & a.m. & p.m. & a.m. & p.m. & a.m. & p.m. & a.m. & p.m. & a.m. & p.m. & a.m. & p.m. \\
\hline Pulse & . & .. & $\begin{array}{l}92 \\
92\end{array}$ & 86 & $\begin{array}{l}92 \\
98 \\
92\end{array}$ & $\begin{array}{l}88 \\
88\end{array}$ & $\begin{array}{r}100 \\
90 \\
90\end{array}$ & $\begin{array}{r}90 \\
108\end{array}$ & $\begin{array}{l}100 \\
100\end{array}$ & $\begin{array}{l}92 \\
80\end{array}$ & $\begin{array}{l}80 \\
84 \\
80\end{array}$ & $\begin{array}{l}82 \\
78\end{array}$ & 84 & $\begin{array}{l}80 \\
80\end{array}$ & $\begin{array}{l}82 \\
88\end{array}$ \\
\hline Respiration & . & . & $\begin{array}{l}20 \\
20\end{array}$ & 20 & $\begin{array}{l}20 \\
20 \\
20\end{array}$ & $\begin{array}{l}20 \\
20\end{array}$ & $\begin{array}{l}20 \\
22 \\
20\end{array}$ & $\begin{array}{l}20 \\
20\end{array}$ & $\begin{array}{l}20 \\
20\end{array}$ & $\begin{array}{l}20 \\
20\end{array}$ & $\begin{array}{l}20 \\
20 \\
20\end{array}$ & $\begin{array}{l}20 \\
20\end{array}$ & 20 & $\begin{array}{l}20 \\
20\end{array}$ & $\begin{array}{l}20 \\
20\end{array}$ \\
\hline Temperatur & e $\left({ }^{\circ} \mathrm{F}\right.$.) & .. & $\begin{array}{l}100 \\
100\end{array}$ & $98 \cdot 4$ & $\begin{array}{l}101 \cdot 8 \\
101 \\
100 \cdot 4\end{array}$ & $\begin{array}{l}99 \\
98.4\end{array}$ & $\begin{array}{r}98 \\
100 \\
100\end{array}$ & $\begin{array}{l}98 \cdot 6 \\
97\end{array}$ & $\begin{array}{l}99 \\
99.6\end{array}$ & $\begin{array}{l}98 \cdot 6 \\
99\end{array}$ & $\begin{array}{l}98 \cdot 4 \\
98 \\
98 \cdot 6\end{array}$ & $\begin{array}{l}98 \cdot 4 \\
97 \cdot 4\end{array}$ & $98 \cdot 4$ & $\begin{array}{l}98 \\
97\end{array}$ & $\begin{array}{l}97 \cdot 2 \\
98 \cdot 4\end{array}$ \\
\hline
\end{tabular}

eyedrops. On January 30 the lesions were dried and crusted and those on the left eyelids had disappeared. The left eye was open and undamaged, and the right cornea could be seen to be unaffected, except for one tiny limbal infiltrate. A crust was removed from one nostril for confirmation of diagnosis.

Fig. 3 was taken on January 31. The lesions cleared rapidly, but some thickness of the lids of the right eye remained. The patient was discharged from hospital on February 16 having been kept perhaps rather longer than necessary (Fig. 4).

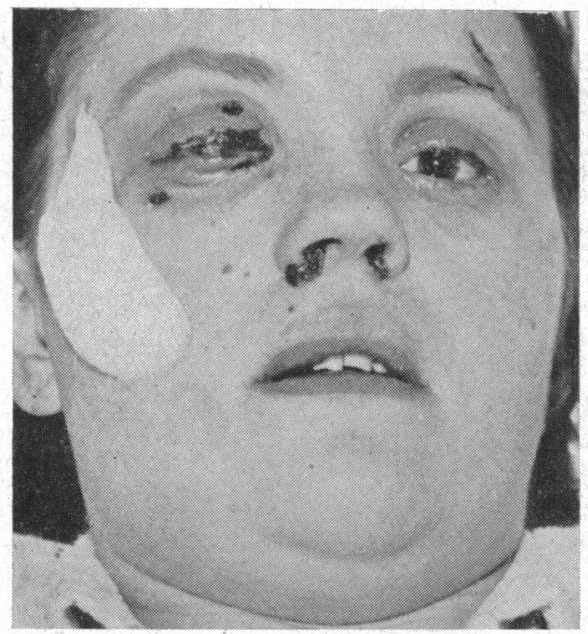

FIG. 3.-Improvement seen 4 days later (January 31, 1956).

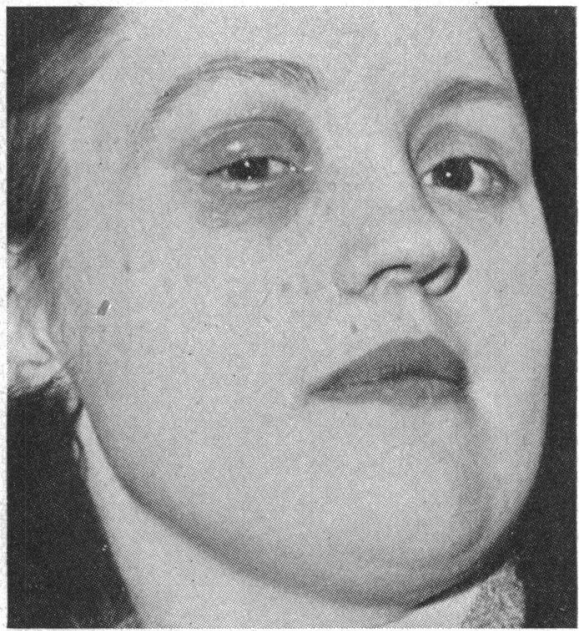

FIG. 4.-Patient's appearance on discharge (February 16, 1956).

Complications.-Some thickness of the upper lid on the right side remains. There are loss of lashes and epiphora due to scar tissue in the region of the right lower punctum and canaliculus. There is also a small symblepharon towards the inner canthus. 


\section{Discussion}

Paschen (1932) reviewed the early literature describing accidental vaccinia at many sites. Duke-Elder (1952) sub-divides accidental vaccinia of the eyelids into two groups:

(a) the isolated lesion;

(b) vaccinia blepharitis.

This case, with additions, falls into the second group. One wonders why the vaccinia spread as it did in this case. It may be argued that the virus is spread by contaminated fingers, but there may also be another explanation:

The spread of vaccinia from the initial site of inoculation, accidental or otherwise is considered to be by way of the blood stream (Ellis, 1935). It has been demonstrated that within 3 to 7 days after vaccination the virus may be present in the naso-pharynx, and that dissemination through the body is haematogenous (Gins, 1929; Collett and Kennedy, 1949).

Watering of the eyes associated with the initial lid lesion on the right side may produce maceration of the skin at the muco-cutaneous junctions of lids and nostrils, and the circumstances thus become akin to the condition of eczema vaccinatum. Some abrasive effect may also be carried out by lid spasm or consciously or subconsciously by wiping, but not necessarily with any contaminated material.

The diagnosis of accidental vaccinia may be simple, but one can imagine circumstances where it might be very difficult (Coriell, Blank, and Scott, 1948). Vaccinia should be considered in the differential diagnosis of any localized, slowly developing vesico-pustular lesion. It may have to be differentiated from syphilis, a simple pyogenic lesion, tubercle, herpes febrilis or zoster, cow-pox, orf, fungus disease, or several tropical lesions.

The diagnosis may be confirmed by culturing the virus on the chorio-allantoic membrane of 10-day-old embryonated chick-eggs (typical plaques being produced on the membrane), or by inoculation of the rabbit cornea with contaminated material (Paul test). Histological sections of the cornea show characteristic basophilic cytoplasmic inclusion bodies of the Guarnieri type (Paul, 1915). A more rapid confirmation may be obtained by examining preparations of pus or scab under the electron miscroscope (Nagler and Rake, 1948).

Among the ocular complications have been described symblepharon, loss of lashes, epiphora, corneal infiltrates and ulcers, disciform keratitis, and rarely retinitis (the last by Franceschetti, 1945).

In an eczematous child the condition of eczema vaccinatum may occur. The mortality rate was described by McKhann and Ross (1938) as 33 per cent. in 1938, so that vaccination or accidental vaccinia in the presence of eczema may be a serious matter. 
Treatment.-Various treatments have been recommended: maintenance of cleanliness, application of various antiseptics, administration of ascorbic acid locally and parenterally, and use of antibiotics. Moffatt (1952) described a case of vaccinia of the conjunctival sac treated with vacciniaimmune serum, and suggested there was "prima facie evidence of benefit obtained from the use of immune serum".

This disease may be self-limiting and in many cases, particularly of autoinoculation, the condition may resolve without complications and with little or no treatment. In other cases, however, resolution may be slow and fraught with danger even to life (as in eczema vaccinatum) and treatment with vaccinia-immune serum or vaccinia gamma-globulin is indicated.

The gamma-globulin is prepared from the plasma of recently vaccinated adults by a special method described by Kekwick and MacKay.

My thanks are due to Dr. Alun Jones, Bacteriologist in the Shrewsbury Group, for his help and advice in confirmation of the diagnosis and treatment, and to the Virus Reference Laboratory, Colindale Avenue, London, N.W.9, for supplying the vaccinia gamma-globulin.

\section{REFERENCES}

Collett, R. W., and Kennedy, R. L. J. (1949). J. Pediat., 34, 284.

Coriell, L. L., Blank, HarVeY, and Scott, T. F. MCNaIR (1948). J. invest. Derm., 11, 313.

DUKe-EldER, S. (1952). "Text-book of Ophthalmology", vol. 5, p. 4881. Kimpton, London.

EluIS, F. A. (1935). J. Amer. med. Ass., 104, 1891.

FranCESCHETTI, A. (1945). Ann. paediat., 165, 200.

Gins, H. A., HaCKenthal, H., and KamentZewa, N. (1929). Z Zbl. Bakt., I. Abt. Orig., 110, Suppl., p. 115.

McKhanN, C. F., and Ross, R. A. (1938). Med. Clin. N. Amer., 22, 785.

MOFFATT, A. B. (1952). British Journal of Ophthalmology, 36, 211.

NAGLER, F. P. O., and RAKE, G. (1948). J. Bact., 55, 45.

PASChen, E. (1932). In J. Jadassohn, "Handbuch der Haut- und Geschlechtskrankheiten", vol. 2 , p. 164 . Springer, Berlin.

Paul, G. (1915). Z Zbl. Bakt., I. Abt. Orig., 75, 518. 